\title{
BONE MINERAL STATUS AND METABOLISM DISORDERS IN PATIENTS WITH CHRONIC SPINAL CORD INJURY
}

\author{
M. A. Bystrytska \\ D. F. CHEBOTAREV INSTITUTE OF GERONTOLOGY OF THE NATIONAL ACADEMY \\ OF SCIENCES OF UKRAINE, KYIV, UKRAINE UKRAINIAN SCIENTIFIC MEDICAL CENTER OF \\ OSTEOPOROSIS, KYIV, UKRAINE
}

\begin{abstract}
Background. The study of late complications, including osteoporosis, is urgent due to the increasing life expectancy of patients with complete spinal cord injury (SCI).

Objective. The aim of the study is to evaluate bone mineral status and bone turnover markers in the patients with chronic SCI.

Methods. 73 SCI patients and 57 healthy persons were examined. Bone status was determined by ultrasound (US) densitometry. Bone turnover markers and vitamin D were evaluated by electrochemiluminescence method. Results. In the SCI patients bone mineral status was significantly lower compared with the individuals of control group. The stiffness index (SI) was $51.4 \pm 11.8 \%$ vs. $98.5 \pm 16.6 \%, p<0.05$ in men and $50.1 \pm 9.8 \%$ vs. $92.9 \pm 11.1 \%$, $p<0.05$ in women. In the SCI patients the levels of bone turnover markers were significantly higher than the reference values. The bone mineral status of patients with SCI, which occurred before peak bone mass development, is significantly worse, compared with the individuals with the already developed peak bone mass,

that makes them a high risk group for fracture.

Conclusions. SCI leads to increased bone resorption with development of secondary osteoporosis (according to the ultrasound densitometry of calcaneal bone). In chronic SCI, bone resorption is higher than in the individuals with combined low levels of vitamin $D$, and the absence of axial load results in continued loss of bone mass.

KEY WORDS: spinal cord injury; osteoporosis; tetraplegia; paraplegia; bone turnover markers; ultrasound densitometry.
\end{abstract}

\section{Introduction}

Improved social adaptation and increased life expectancy of persons with complete spinal cord injury pay attention to late complications of spinal cord injuries (SCI) including osteoporosis and fragility fractures. SCI-induced osteoporosis has been studied since the first half of the 20th century, but no consistent approach to its diagnosis and treatment has been developed. Currently, diagnostic criteria for osteoporosis in postmenopausal women and men over 50 years are established, but the vast majority of SCI patients are young men. Most of studies are devoted to bone changes in the first days, weeks and months after the injury, when intense bone resorption starts. during the fi years after complete spinal cord injury, rapid decrease in bone mass takes place, which reaches $20-50 \%$ of bone mineral density (BMD) of paralyzed limbs [1]. Demineralization of spongy bone occurs faster than that of cortical bone, due to its higher metabolic

Corresponding author: Maryna Bystrytska, D. F. Chebotarev Institute of Gerontology of the National Academy of Medical Sciences of Ukraine, Ukrainian Scientific Medical Center of Osteoporosis, 67, Vyshgorodska Str., Kyiv, 04114, Ukraine E-mail: miroslava_br@ukr.net

Phone number: +380674185573 activity [1]. Also there is no consensus for increased resorption duration after SCI. Some studies have proved that bone loss slows down 3-5 years after the injury [2]. Other study findings evidenced continued bone loss in later stages of the post-traumatic period $[3,4]$. The extent and duration of bone loss are caused by many factors, which depend on the characteristics of the injury as well as on many parameters of various systems of the patient. The significance of a degree of spinal cord injury and opportunities for verticalization and movement of bone loss has been proved, but the role of factors affecting bone tissue in the patients with complete spinal cord injury has not been defined so far.

Objective of the study is to evaluate the bone mineral status and parameters of bone metabolism in the patients with chronic spinal cord injuries.

\section{Methods}

73 people who suffered a spinal trauma with complete spinal cord injury with tetra- or paraplegia were examined: 38 men, average age $40.1 \pm 12.2$ years old; 35 women, average age $41.3 \pm 11.3$ years old; duration of the post-traumatic period was $15.7 \pm 10.6$ years. Patient 
examination was conducted in cooperation with the Association of Disabled Persons with Spinal Cord injuries. the examined patients lead an active lifestyle that excluded the impact of prolonged bed rest. volunteers accompanying people with $\mathrm{SCi}$ were also examined as a comparison group. volunteers were usually represented by patients' relatives: parents, children, spouses, which could partially reduce the impact of other factors affecting bone tissue, including eating habits, living environment, and genetic factors.

Bone status was determined by ultrasound (US) densitometry of calcaneal bone using quantitative ultrasonometer Sahara (Hologic Inc., model 04874, 2008). Ultrasound densitometry evaluated: speed of sound ( $\mathrm{SoS}, \mathrm{m} / \mathrm{s}$ ); broadband ultrasound attenuation (BUA, dB/ $\mathrm{MHz}$ ); stiffness index (SI, \%), calculated by computer on the basis of SOS and BUA parameters; extrapolated mineral density of calcaneal bone; T-score (patient's SI difference from the index of conventionally healthy adults aged 20 years old was presented in standard deviations); Z-index (patient's SI difference from the index of conventionally healthy adults of the same age was presented in standard deviations).

Bone remodelling markers in peripheral blood (osteocalcin, procollagen type 1 propeptide (P1NP), collagen type 1 cross-linked C-telopeptide $(\beta-C T x))$ were defined by electrochemiluminescence method on the analyser Elessys 2010 (Roche Diagnostics, Germany) using cobas testsystems.

The statistical analysis was performed using Statistica 10 software. Results were presented as mean values and standard deviation $(\mathrm{M} \pm \mathrm{m})$. The difference in parameters between the groups was defined using one-way analysis of variance ANOVA. Intergroup differences were evaluated by Scheffe's test. The difference in parameters was statistically significant at $\mathrm{p}<0.05$.

\section{Results}

The results of ultrasound densitometry of the individuals of the main group proved low bone mineral density (Z-score $\leq-2.0 \mathrm{Sd}$ ) in all women of reproductive age $(n=21)$ and all men younger than 50 years old $(n=25)$. Osteoporosis (T-score $\leq-2.5 \mathrm{Sd}$ ) was evidenced in 12 postmenopausal women and 13 men older than 50 years. None of the patients with spinal cord injuries had normal parameters of bone tissue structural-functional state. In the patients of control group, osteoporosis was not diagnosed, low bone mineral density was revealed in 10 individuals ( 3 men and 7 women), in all postmenopausal women, and 2 men older than 50 years.

The results of ultrasound densitometry in the patients with spinal cord injuries proved significantly lower parameters of bone density compared with those of the control group (Tabl. 2).

It should be noted that the analysis of data in Tabl. 2 proved no impact of gender on the parameters of bone mineral status ( $p>0.05)$. there was also no significant dependence of bone parameters on age, height, injury level and duration.

Significant moderate correlation between SI and body weight was obtained in men of the main group. Relationship was described by the linear regression equation: SI $(\%)=8.01+0.55$ * weight $(\mathrm{kg}) ; r=0.41 ; p=0.017 ; r 2=0.17$. In the women no influence of anthropometric data on bone mineral status was revealed.

Bone mineral density was found to depend on the trauma age in men $(r=0.41 ; p=0.019$; $\left.r^{2}=0.16\right)$ and women of reproductive age $\left(r=0.40 ; p=0.048 ; r^{2}=0.16\right)$.

It is established that complete spinal cord injury leads to intensive bone loss in the first years after the injury [5]. Furthermore, the rate of loss slows down and the studied bone parameters are less dependent on the duration

Table 1. Characteristic features of the examined SCI patients and persons of control group

\begin{tabular}{|c|c|c|c|c|c|c|}
\hline Parameter & \multicolumn{2}{|c|}{ Main, $n=73$} & \multicolumn{2}{|c|}{ Control, $\mathrm{n}=57$} & \multicolumn{2}{|c|}{$\mathrm{P}$} \\
\hline Gender & Men, $n=38$ & Women, $\mathrm{n}=35$ & Men, $n=21$ & Women, $n=36$ & Men & Women \\
\hline Age, years & $40.10 \pm 12.20$ & $41.30 \pm 11.30$ & $39.70 \pm 13.80$ & $46.80 \pm 12.20$ & 0.91 & 0.06 \\
\hline Height, cm & $178.60 \pm 7.20$ & $164.10 \pm 5.60$ & $177.30 \pm 5.60$ & $163.20 \pm 5.80$ & 0.48 & 0.52 \\
\hline Weight, kg & $72.90 \pm 9.10$ & $59.20 \pm 5.70$ & $71.20 \pm 10.60$ & $62.30 \pm 9.60$ & 0.51 & 0.11 \\
\hline BMI, $\mathrm{kg} / \mathrm{cm}^{2}$ & $22.90 \pm 2.90$ & $22.10 \pm 2.20$ & $22.70 \pm 3.30$ & $23.50 \pm 4.00$ & 0.77 & 0.01 \\
\hline Trauma age, years & $23.60 \pm 7.50$ & $26.50 \pm 8.30$ & - & - & - & - \\
\hline Trauma duration, years & $16.50 \pm 11.40$ & $14.90 \pm 6.60$ & - & - & - & - \\
\hline Trauma level & $\begin{array}{c}\mathrm{C}_{4-6}=9 \\
\mathrm{Th}_{2-12}=19 \\
\mathrm{~L}_{1}=11\end{array}$ & $\begin{array}{c}C_{6}=1 \\
T_{4-12}=22 \\
L_{1}=12\end{array}$ & - & - & - & - \\
\hline
\end{tabular}


Table 2. Bone mineral status in the patients with chronic spinal cord injury and persons of control group

\begin{tabular}{|l|c|c|c|c|}
\hline \multirow{2}{*}{ Parameter } & \multicolumn{2}{c|}{ Men } & \multicolumn{2}{c|}{ Women } \\
\cline { 2 - 5 } & Main group & Control group & Main group & Control group \\
\hline T-score & $-3.20 \pm 0.80 *$ & $-0.40 \pm 0.80$ & $-3.10 \pm 0.50 *$ & $-0.60 \pm 0.60$ \\
\hline Z-index & $-2.70 \pm 0.70 *$ & $0.40 \pm 0.20$ & $-2.90 \pm 0.50 *$ & $-0.40 \pm 0.60$ \\
\hline SI & $51.40 \pm 11.80 *$ & $98.50 \pm 16.60$ & $50.10 \pm 9.80 *$ & $92.90 \pm 11.10$ \\
\hline extrapolated BMd & $0.25 \pm 0.00^{*}$ & $0.55 \pm 0.10$ & $0.24 \pm 0.06 *$ & $0.51 \pm 0.07$ \\
\hline BUA & $40.50 \pm 13.80^{*}$ & $78.70 \pm 15.70$ & $37.40 \pm 12.70 *$ & $76.90 \pm 11.30$ \\
\hline SUP & $1477.00 \pm 19.00^{*}$ & $1554.00 \pm 26.00$ & $1473.00 \pm 25.00 *$ & $1542.00 \pm 18.00$ \\
\hline
\end{tabular}

Note: $*-p<0.05$, differences in parameters of the main and control groups.

of post-traumatic period, but there is a proven relationship of osteoporosis risk and bone characteristic features at the time of the injury [6].

The results of the study performed by Professor V Povoroznyuk in 1998 prove that in the Ukrainian population women reach peak bone mass at the age of 23-24 years old and men - at the age of 25-26 [7]. In present study, patients were divided into 2 subgroups according to their trauma age. A cutting-off point for men was 25 years and for women -23 years of age.

In the patients with the injury that occurred before reaching peak bone mass, the bone mineral status according to ultrasound densitometry was significantly worse than that of the patients of corresponding age, anthropometric parameters and duration of the posttraumatic period with the onset of injury at the age over 23 and 25 years, respectively (Fig. 1, 2).

No difference was proved in the bone mineral status of the women depending on their age at the injury onset, but after excluding postmenopausal women from both study groups, it was found out that bone mineral status was significantly worse in the women with trauma at the age of 23 years old (Fig. 2).

A significant difference in stiffness index in the women of reproductive age and postmenopausal women was not evidenced due to small size and heterogeneity of sample. In addition, the impact of menopause should be considered in certain groups of women, depending on the age at the injury onset before or after reaching peak bone mass.

Among the examined individuals, 18 patients had fractures of hip (11 patients) or tibia fractures (7 patients) due to a low-energy trauma in the period after a spinal cord injury. $66 \%$ of them had a spinal cord injury at the age of 25 years old $(p=0.001)$. Other differences between the group of patients with fractures and without fractures were not detected.

Bone metabolism according to remodelling markers was analysed separately for women and men, and compared with the reference data for the Ukrainian population (Table 3) [8].

According to the results of previous studies, bone metabolism is much increased after SCI, and then it gradually decreases, but remains high in the first years after the injury [4]. This paper proves that bone remodelling markers remain elevated in the later period of the injury as well (traumatic disease duration from 5 to 38 years, average duration $-14.7 \pm 1.2$ ). In both women and men with SCI, tP1NP levels are significantly higher than the reference values. Men are also characterized by higher levels of bone resorption marker ( $\beta-C T x)$. the level of

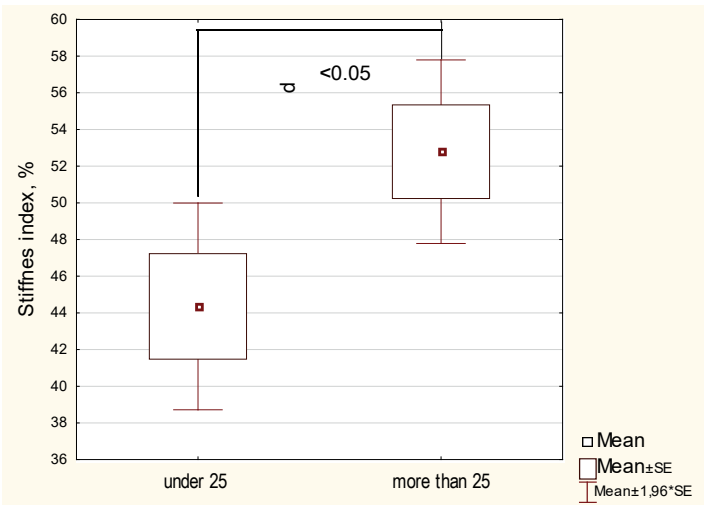

Fig. 1. Bone mineral status of men depending on the spinal cord injury age.

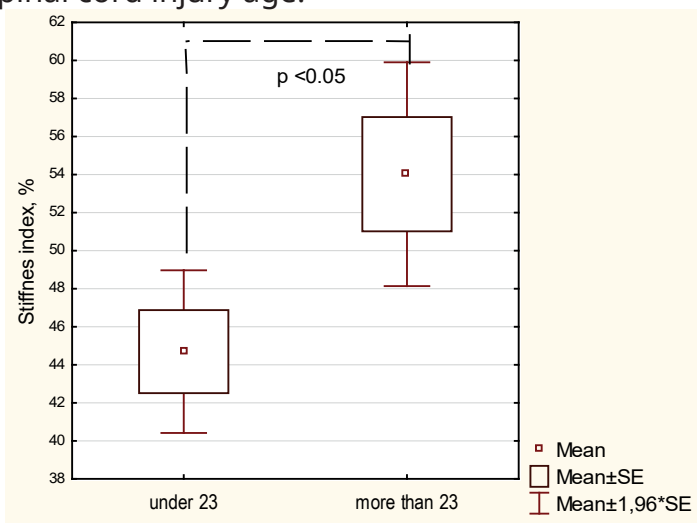

Fig. 2. Bone mineral status of reproductive age women with SCI depending on the age at trauma incidence. 
vitamin D3 is significantly lower in the SCI patients than the reference values. no significant relationships of the levels of bone remodelling markers and SCI duration were evidenced, but upon division of patients into 2 groups depending on the post-traumatic period duration: subgroup $A<14.7$ and subgroup $B>14.7$ years, the $\beta$-CTx level was significantly higher in subgroup $A, 0.55 \pm 0.07 \mathrm{pg} / \mathrm{ml}$, in subgroup $B$ $0.39 \pm 0.04 \mathrm{pg} / \mathrm{ml}, \mathrm{t}=2.4, \mathrm{p}<0.05$, proving gradual slowing of the destruction process in the late posttraumatic period.

\section{Discussion}

Increased bone resorption in the SCI patients occurs very quickly after the injury and affects bones below the spinal cord injury. According to the results of previous studies, the patients with signs of complete spinal cord injury, who had a fragility fracture, were diagnosed with a significant loss of bone mineral density in the distal femur (54\%) and distal tibia bone (73\%), which took place for the first 5-7 years after the injury [5]. Interestingly that bone loss is greater in the distal section. The above trend suggests that at the level of calcaneal bone, the loss will be even greater, also due to a higher content of spongy bone in the calcaneal bone. The use of ultrasound densitometry of calcaneal bone as a screening method in the diagnosis of osteoporosis is based on the close relationship of parameters of vertebral bone and calcaneal bone. In the SCI patients, this relationship is missing. After the complete spinal cord injury, bone changes differently depend on the location. In parts of the skeleton, located above the injury level, bone mineral density decreases immediately after the injury, but gradually returns to normal parameters and even increases with increased load, such as bone mineral density of upper limbs in the patients with paraplegia. In the sections below the injury, with impaired innervation and reduced static load, such as lower limbs, bone mineral density decreases progressively [4, 9]. Thus, regardless of the injury level, the lumbar vertebrae and calcaneal bone is in different conditions and changes in them are opposite. distal femur and proximal tibia are the most frequent localization of fractures in these patients and therefore an area of interest. These areas consist mainly of spongy bone and are closer in composition to calcaneal bone, therefore lose bone tissue in a similar way in the absence of axial load and adequate trophic effects.

The results of ultrasound densitometry of calcaneal bone can also diagnose osteoporosis, but according to the literature the capabilities of this method in the follow up of SCI patients are limited [8-10]. The loss of bone tissue after a severe spinal injury develops rapidly, resulting in the development of osteoporosis and significantly increased fracture risk, but after 3-5-10 years, the rate of bone resorption slows down. Further, the post-traumatic period duration has less effect on the bone mineral status [4]. Inverse correlation was proved between the post-traumatic period duration and the number of proximal tibia trabecules that confirmed the continued predominance of resorption processes in spongy bone. Simultaneously, the thinning of cortical layer of long bones of lower extremities took place, but the loss of cortical layer occurred much more slowly than that of trabecular bone. Slow cortical layer thinning may explain the fact that the average period until the first fracture in SCI patients is 9 years after the injury [3]. Thus, correction of structural-functional state of bone as fracture prevention has quite a large therapeutic window - 9 years. Among the leading risk factors for osteoporosis in the SCI patients along with severity of the injury and absence of axial load in the post-traumatic period, the low baseline values of mineral density and high levels of markers of bone remodeling are present [11]. This coincides with the results of our study. The patients, who had injury before bone mass peak, have lower parameters of structural and functional state of bone and increased risk of fractures. All patients in our study had low bone mineral density (according to Z-criterion or T-score, depending on the age). According to the 2014 National Osteoporosis Foundation guidelines, $\mathrm{SCI}$ is one of the diseases and conditions that contribute to the development of osteoporosis and fractures, and therefore the patients with SCI and low bone mineral

Table 3. Bone turnover markers and vitamin D level in the SCI patients

\begin{tabular}{|l|c|c|c|c|c|c|}
\hline \multirow{2}{*}{$\begin{array}{c}\text { Bone metabolism } \\
\text { parameters }\end{array}$} & \multicolumn{2}{|c|}{$\begin{array}{c}\text { Bone metabolism } \\
\text { reference values }\end{array}$} & $\begin{array}{c}\text { Bone metabolism parame- } \\
\text { ters in the SCI patients }\end{array}$ & \multicolumn{2}{c|}{$P$} \\
\cline { 2 - 7 } & For men & For women & In men & In women & men & women \\
\hline tP1NP, $\mathrm{ng} / \mathrm{ml}$ & $34.50 \pm 5.80$ & $44.70 \pm 4.40$ & $43.80 \pm 4.30$ & $57.40 \pm 4.50$ & $<\mathbf{0 . 0 5}$ & $<\mathbf{0 . 0 5}$ \\
\hline $\mathrm{OC}, \mathrm{ng} / \mathrm{ml}$ & $24.30 \pm 1.70$ & $23.40 \pm 1.50$ & $24.50 \pm 1.90$ & $19.60 \pm 1.50$ & $>0.05$ & $<\mathbf{0 . 0 5}$ \\
\hline$\beta-\mathrm{Ctx}, \mathrm{ng} / \mathrm{ml}$ & $0.37 \pm 0.06$ & $0.41 \pm 0.07$ & $0.58 \pm 0.05$ & $0.36 \pm 0.04$ & $<0.05$ & $>0.05$ \\
\hline $25(\mathrm{OH}) \mathrm{D} 3, \mathrm{nmol} / \mathrm{ml}$ & $44.60 \pm 5.20$ & $40.40 \pm 5.60$ & $26.80 \pm 7.80$ & $20.30 \pm 4.50$ & $<0.05$ & $<0.05$ \\
\hline
\end{tabular}


density can be diagnosed with secondary osteoporosis. The prevalence of this condition among the SCI patients encourages further researches.

\section{Conclusions}

SCI leads to increased bone resorption with development of secondary osteoporosis (according to the ultrasound densitometry of calcaneal bone). In chronic SCI, bone resorption is higher than in the individuals with combined low levels ofvitamind, and the absence of axial load results in continued loss of bone mass.

\section{Acknowledgments}

I appreciate the help of the Ukrainian Association of Osteoporosis (the President - Professor Povoroznyuk V. V.) and Association of Disabled Persons with Spinal Cord Injuries (the President - Marusevych I. M.) in conducting research.

\section{ЗМІНИ МІНЕРАЛЬНОЇ ЩЛЬНОСТІ ТА МЕТАБОЛІЗМУ КІСТКОВОЇ ТКАНИНИ В ПАЦІЄНТІВ ЗІ СПІНАЛЬНОЮ ТРАВМОЮ}

\section{М. А. Бистрицька \\ ДУ «ІНСТИТУТ ГЕРОНТОЛОГЇ̈ ІМ. Д. Ф. ЧЕБОТАРЬОВА НАМН УКРАЇНИ», КИЇВ, УКРАЇНА УКРАЇНСЬКИЙ ЦЕНТР ЛІКУВАННЯ ОСТЕОПОРОЗУ, КИЇВ, УКРАЇНА}

Вступ. Вивчення пізніх ускладнень при травмах спинного мозку, у тому числі остеопорозу, є актуальним через збільшення тривалості життя таких пацієнтів.

Мета дослідження визначити мінеральну щільність та особливості метаболізму кісткової тканини ухворих із травматичною хворобою спинного мозку.

Методи. Обстежено 73 хворих із травмами спинного мозку та 57 здорових осіб. за допомогою ультразвуковоі денситометрії визначили мінеральну щільність кісток; маркери ремоделювання кісткової тканини та вміст вітаміну Д стан - методом електрохімілюмінесценції.

Результати. Ухворих із травмами спинного мозку стан мінерального компонента кісткової тканини був значно нижчим порівняно з хворими контрольної групи. Індекс міцності кісткової тканини становив $51,4 \pm 11,8 \%$ у порівнянні

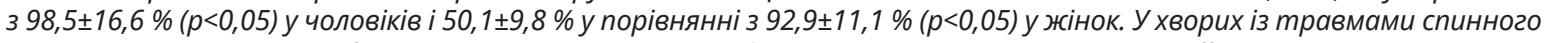
мозку рівень маркерів ремоделювання кісткової тканини був значно вищим, ніжу контрольній групі. Стан мінерального компонента кісткової тканини у хворих із травмами спинного мозку значно гірший, порівняно з особами з вже розвинутою піковою кістковою масою, що дає змогу їх віднести до групи підвищеного ризику виникнення переломів.

Висновки. Травми спинного мозку зумовлюють посилення резорбиії кістки з розвитком вторинного остеопорозу (за даними ультразвукової денситометрії п'яткової кістки). Процеси резорбції є значно інтенсивнішими при травмах спинного мозку у хворих із низьким рівнем вітаміну $D$, а також при відсутності осьового навантаження.

КЛЮЧОВІ СЛОВА: травма спинного мозку; остеопороз; тетраплегія; параплегія; маркери ремоделювання кісткової тканини; ультразвукова денситометрія

\section{References}

1. Dolbow JD, Dolbow DR, Gorgey AS, Adler RA, Gater DR. The effects of aging and electrical stimulation exercise on bone after spinal cord injury. aging dis. 2013;4(3):141-53.

2. Frotzler A, Berger $M$, Knecht $H$, Eser P. Bone steady-state is established at reduced bone strength after spinal cord injury: a longitudinal study using peripheral quantitative computed tomography (pQCT). Bone.2008;43(3):549-55. doi:10.1016/j. bone.2008.05.006.

3. Battaglino RA, lazzari AA, Garshick E, Morse IR. Spinal cord injury-induced osteoporosis: pathogenesis and emerging therapies. Curr Osteoporos Rep. 2012;10(4):278-85. doi: 10.1007/s11914-012- 0117-0.

4. Bauman WA, Cardozo CP. Osteoporosis in individuals with spinal cord injury. PM\&R. 2015 Feb 1;7(2):188-201. doi: 10.1016/j.pmrj.2014.08.948.

5. Bryson JE, Gourlay MI. Bisphosphonate use in acute and chronic spinal cord injury: a systematic review. J Spinal Cord Med. 2009;32(3):215-25.

6. Gifre I, Vidal J, Carrasco Jl, Muxi A, Portell E, Monegal A et all. Risk factors for the development of osteoporosis after spinal cord injury. A 12-month follow-up study Osteoporos Int. 2015;26(9):2273-80. doi: $10.1007 /$ s00198-015-3150-x.
7. Povoroznyuk VV, Orlyk TV, Kreslov YeO. A modern view of the problem of osteoporosis in men in ukraine. Pain. Joints. Spine. 2012: 2(6). http://www. mif-ua.com/archive/article_print/34335. [In Ukrainian].

8. Vaida VM. (Donetsk National Medical University). Gender and age features of osteoporosis and its complications. Donetsk; 2011.310 p. [In Ukrainian].

9. Bittar C, Cliquet A. Utility of quantitative ultrasound of the calcaneus in diagnosing osteoporosis in spinal cord injury patients. American Journal of Physical Medicine \& Rehabilitation. 2011 Jun;90(6):477-81. PMid: 21765270. doi: 10.1097/ PHM.0b013e31821a7386.

10. Chow YW, Inman C, Pollintine P, Sharp CA, et al. Ultrasound bone densitometry and dual energy X-ray absorptiometry in patients with spinal cord injury: a cross-sectional study. Spinal Cord.1996; 34:736-41. doi: 10.1038/sc.1996.134.

11. Cosman F, de Beur SJ, LeBoff MS, et al. Clinician's Guide to Prevention and Treatment of osteoporosis. osteoporos int. 2014 oct;25(10):235981. PMid: 25182228. PMCid: PMC4176573. doi: 10.1007/s00198-014-2794-2. 